\title{
Clinical and cytological spectrum of thyroid lesions and the role of fine needle aspiration cytology in its diagnosis at a tertiary care hospital
}

\author{
Akshatha N. ${ }^{1}$, Patil S. ${ }^{2 *}$, P Bommanahalli B. ${ }^{3}$ \\ DOI: https://doi.org/10.17511/jopm.2019.i08.03 \\ ${ }^{1}$ Akshatha N, Assistant Professor, Department of Pathology, Gadag Institute of Medical Sciences, Gadag, Karnataka, India. \\ 2* Shwetha Patil, Post MD Tutor, Department of Pathology, Gadag Institute of Medical Sciences, Gadag, Karnataka, India. \\ 3 Basavaraj P Bommanahalli, Professor and Head, Department of Pathology, Gadag Institute of Medical Sciences, Gadag, Karnataka, India. \\ Background: Thyroid lesions are one of the significant clinical problems encountered in most of \\ patients coming to the tertiary care units. Fine Needle Aspiration Cytology (FNAC) is the present \\ day's worldwide accepted diagnostic tool as it is a cost effective, minimally invasive, low \\ complication, non-operative method and has a high sensitivity and specificity in most of thyroid \\ lesions. Fine Needle Aspiration Cytology can be used in the diagnosis of these lesions and hence \\ categorising them into benign / inflammatory / neoplastic and aiding the clinician in the next step of \\ surgical / medical management and reduces the unwanted surgeries. Aim: To study the clinical and \\ cytological spectrum of thyroid lesions encountered in everyday practice. Materials and Methods: \\ This was a retrospective study conducted over the period of 1 year and 1 month, from January 2018 \\ to January 2019 in department of pathology Gadag Institute Medical Science, Gadag. A total of 101 \\ Patients with thyroid lesions who underwent Fine Needle Aspiration procedure were identified and \\ their clinical details, available biochemical and radiological parameters were collected, and cyto- \\ morphological features were studied. The lesions were categorised into benign, inflammatory, \\ Follicular neoplasm, malignant and inadequate. Results: Out of 101 cases studied, 47 (46.5\%) were \\ Benign, 33 (32.6\%) were Inflammatory,09 (8.9\%) cases were Follicular Neoplasm and 04 (3.9\%) \\ cases were Malignant while $09(8.9 \%)$ cases were inadequate. Conclusions: FNAC is one of the \\ simple useful primary diagnostic tool for the identification and categorization of thyroid lesions. It is \\ safe, cost-effective, minimally invasive and sensitive technique for its diagnosis.
}

Keywords: Fine needle aspiration cytology, Thyroid nodule, Thyroiditis fnac

Corresponding Author

Shwetha Patil, Post MD Tutor, Department of Pathology, Gadag Institute of Medical Sciences, Gadag, Karnataka, India.

Email: shwetavpatil $90 @ g m a i l . c o m$

\section{How to Cite this Article}

Akshatha N, Shwetha Patil, Basavaraj P Bommanahalli, Clinical and cytological spectrum of thyroid lesions and the role of fine needle aspiration cytology in its diagnosis at a tertiary care hospital. Trop J Pathol Microbiol. 2019;5(8):523-528. Available From

https://pathology.medresearch.in/index.php/jopm/ar ticle/view/299

\section{To Browse}

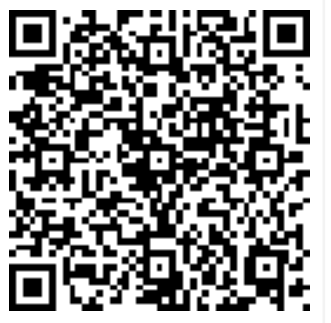

Manuscript Received 2019-07-08

Conflict of Interest No

Review Round 1
2019-07-14
Funding
Nil

Cil

(C) 2019 by Akshatha N, Shwetha Patil, Basavaraj P Bommanahalli and Published by Siddharth Health Research and Social Welfare Society. This is an Open Access article licensed under a Creative Commons Attribution 4.0 International License https://creativecommons.org/licenses/by/4.0/ unported [CC BY 4.0].

\author{
Review Round 2 \\ 2019-07-24 \\ Ethical Approval \\ Yes
}

Accepted 2019-07-29

Note 


\section{Introduction}

The thyroid gland is the largest endocrine organ which plays vital role in body metabolism. A unique feature of Thyroid lesions is that both nonneoplastic and neoplastic diseases affect it and lead to diffuse or nodular enlargement. Non-neoplastic lesions are comparatively more common in thyroid like goitre, thyroiditis and graves' disease [1]. Even after much advances in the field of endocrinology, the thyroid gland still remains a subject of keen interest and importance due to the broad spectrum of lesions and presentations [2].

Fine Needle Aspiration Cytology (FNAC) is the present day's worldwide accepted diagnostic tool as it is a cost effective, minimally invasive, low complication, non-operative method and has a high sensitivity and specificity in most of thyroid lesions [2].

As a diagnostic test, FNAC can diagnose most benign lesions, inflammatory lesions as well as malignant lesions. The test can be used to differentiate thyroid lesions which require surgical excision from conditions which can be managed medically [3].

However, the success of FNA is contingent upon several important contributing influences including aspirator experience, skillful cytological interpretation and a rational analysis based upon a synthesis of cytological and clinical information in the context of an individual patient[4].

Objectives: To study the spectrum of clinical presentation of individuals with thyroid lesions and correlate the clinical diagnosis with the Biochemical, radiological and cytomorphological features.

\section{Materials and Methods}

Study Setting: Gadag Institute of Medical Sciences, Gadag

Study Duration: January 2018 to January 2019

Type of Study: Retrospective study

Sample Size: A total of 101 case files were retrieved, consisting of all the patients having thyroid lesions who underwent the procedure of FNAC

Inclusion criteria: All the cases which have underwent FNAC in the study hospital and Complete Report of the FNAC was available

\section{Exclusion criteria:Incomplete FNAC Reports}

Data collection and analysis- The relevant patient data including clinical details, available biochemical and radiological parameters were tabulated and analyzed.The cytological smears (Papanicolaou, H\&E and Geimsa) were reviewed and categorized into five different categories namely benign, inflammatory, Follicular Neoplasm, malignant lesions and inadequate.

The Benign category included smears with adequate cellularity, showing abundant colloid, follicular cells in flat sheets or micro follicular clusters, unremarkable morphology, with/without colloid laden macrophages or cyst macrophages.

The Inflammatory category included smears with a lymphocytic background, hurthle cells change with / without other inflammatory cells / giant cells.

The follicular neoplasm category included smears with moderate or high cellularity showing follicular cells in 3 dimentional clusters, microfollicles, overlapping nuclei in a background of absent or scant colloid. Care was taken that the follicular cells did not include any nuclear features of Papillary Carcinoma Thyroid.

Malignancy category included smears with features consistant with malignant neoplasms of thyroid including papillary carcinoma, medullary carcinoma, anaplastic carcinoma and hurthle cell neoplasm.

Inadequate samples included smears with scant cellularity ( $<6$ well preserved follicular clusters in at least 2 slides) showing predominantly haemorrhage. However, if the hypocellular smears shows abundant colloid with cyst / colloid laden macrophages, they were classified under the benign category.

\section{Results}

Out of the total 101 study samples, nearly $68.4 \%$ of the study subjects were between the age group of 20 to 50 years of age.

Table-1: Age distribution

\begin{tabular}{|l|l|}
\hline \multicolumn{1}{|c|}{ Age (in years) } & \multicolumn{1}{c|}{ Number $(\mathrm{n}=\mathbf{1 0 1})$} \\
\hline$<20$ & $12(11.8 \%)$ \\
\hline $20-50$ & $69(68.4 \%)$ \\
\hline$>50$ & $20(19.8 \%)$ \\
\hline
\end{tabular}

Table-2: Clinical presentation

\begin{tabular}{|l|l|}
\hline \multicolumn{1}{|c|}{ Clinical symptoms } & \multicolumn{1}{c|}{ Number $(\mathbf{n}=\mathbf{1 0 1})$} \\
\hline Enlargment & $101(100 \%)$ \\
\hline Tenderness & $23(22.7 \%)$ \\
\hline
\end{tabular}


Akshatha N. et al: Clinical and cytological spectrum of thyroid

\begin{tabular}{|l|l|}
\hline Dysphagia & $9(8.9 \%)$ \\
\hline Voice change & $7(6.9 \%)$ \\
\hline Hypothyroidism features & $24(23.7 \%)$ \\
\hline Hyperthyroidism Features & $1(0.9 \%)$ \\
\hline
\end{tabular}

The majority of the clinical presentation of the study subjects was enlargement of the thyroid gland in all the cases. Nearly $22.7 \%$ had tenderness, $8.9 \%$ had dysphagia, $6.9 \%$ presented with voice changes, $23.7 \%$ presented with hypothyroidism features and $0.9 \%$ with hyperthyroidism features.

\section{Table-3: Thyroid function test}

\begin{tabular}{|l|l|}
\hline \multicolumn{1}{|c|}{ Thyroid function test } & \multicolumn{1}{c|}{ Number $(\mathbf{n}=101)$} \\
\hline Euthyroid & $54(53.4 \%)$ \\
\hline Hypothyroid & $22(21.7 \%)$ \\
\hline Hyperthyroid & $1(1.99 \%)$ \\
\hline Not Available & $24(23.7 \%)$ \\
\hline
\end{tabular}

In the study subjects nearly $53.4 \%$ of the study subjects had euthyroid, $21.7 \%$ presented with Hypothyroid, $1.99 \%$ with hyperthyroid and $23.7 \%$ nothing was available.

Table-4: Clinical and radiological diagnosis of the study subjects:

\begin{tabular}{|l|l|l|}
\hline \multicolumn{1}{|c|}{ Diagnosis } & \multicolumn{1}{|c|}{$\begin{array}{c}\text { Clinical } \\
\text { diagnosis }\end{array}$} & \multicolumn{1}{|c|}{$\begin{array}{c}\text { Radiological } \\
\text { diagnosis }\end{array}$} \\
\hline Colloid goitre & $68(67.3 \%)$ & $43(42.5 \%)$ \\
\hline Thyroiditis & $19(18.8 \%)$ & $22(21.7 \%)$ \\
\hline Solitary thyroid nodule & $6(5.95 \%)$ & $5(4.9 \%)$ \\
\hline Malignancy & $2(1.9 \%)$ & $3(2.9 \%)$ \\
\hline $\begin{array}{l}\text { Nodular colloid goitre with cystic } \\
\text { change }\end{array}$ & $0(0 \%)$ & $1(0.99 \%)$ \\
\hline Not mentioned & $6(5.9 \%)$ & $27(26.7 \%)$ \\
\hline
\end{tabular}

The clinical diagnosis was established in all the cases of the study subjects. Majority (67.3\%) of them presented with colloid goiter ,18.8\% presented with Thyroiditis, $5.95 \%$ with solitary thyroid nodule, $1.9 \%$ with malignancy and $5.9 \%$ no diagnosis could be achieved.

Where as in radiological diagnosis colloid goiter was established in $42.5 \%$ of the subjects, thyroiditis in $21.7 \%$, solitary thyroid nodule $4.9 \%$, malignancy in $2.9 \%$ and $0.99 \%$ had nodular colloid goiter with cystic changes.

\section{Table-5: Cytological diagnosis}

\begin{tabular}{|l|l|}
\hline \multicolumn{1}{|c|}{ Cytological diagnosis } & Number $(n=101)$ \\
\hline Benign $(n=47: 46.5 \%)$ & $40(39.6 \%)$ \\
\hline Colloid goitre & $04(3.9 \%)$ \\
\hline Nodular colloid goitre with cystic change & $1(0.99 \%)$ \\
\hline Hyperthyroid - graves & \\
\hline Inflammatory $(n=34: 33.6 \%)$ &
\end{tabular}

\begin{tabular}{|l|l|}
\hline Hashimotosthyroiditis & $30(29.7 \%)$ \\
\hline Thyroiditis (lymphocytic) & $04(3.9 \%)$ \\
\hline Follicular neoplasm & $09(8.9 \%)$ \\
\hline Malignancy & $04(3.9 \%)$ \\
\hline Inadequate & $09(8.9 \%)$ \\
\hline
\end{tabular}

Out of 101 cases studied, $47(46.5 \%)$ cases were diagnosed as benign, $33(32.6 \%)$ cases were diagnosed as inflammatory, $09(8.9 \%)$ cases were diagnosed as Follicular Neoplasm, 04 (3.9\%) cases were diagnosed as malignant and $09(8.9 \%)$ cases were inadequate.

\section{Discussion}

Out of the 101 casesthe male to female ratio was 1:7.41 (Males $=12$ and Females $=89$ ). A similar finding was noted in a study by Sameer et al [2] andKhadatkar et al[1] where a clear female predominance was observed. The age-wise distribution among the study population. The maximum number of patients belonged to the age group between 20-50 years, which was also noted in the study by Sameer et al [2] and Khadatkar et al [1]. The patients presented with various clinical symptoms likeEnlargement of thyroid gland was seen in all the patients $(100 \%)$, symptoms of thyroiditis like tenderness was noted in 23 cases $(22.7 \%)$, while pressure symptoms like Dysphagia and voice change was seen in 9 (8.95) and $7(6.9 \%)$ cases respectively. Features of Hypothyroidism was seen in $24(23,7 \%)$ cases, while hyperthyroidism features was seen in one $(0.99 \%)$ case. Similar presentation were seen in a study done by Uma et al [4] as well Sameer et al[2].

The clinical diagnosis was mentioned in 95 out 101 cases, of which $68(67.3 \%)$ cases were diagnosed as colloid goitre, $19(18.8 \%)$ cases were diagnosed as thyroiditis, $6(5.9 \%)$ cases were diagnosed as Solitary Thyroid nodule and $2(1.9 \%)$ cases were diagnosed as malignancy which were similar to the results seen in study by Uma et al[4] and Dhanadia et al[5] The patients with Thyroiditis fell in the middle age group and showed a diffuse enlargement of the gland. On retrieving the biochemical parameters of the study population, it was noted that the Thyroid function tests which was available in 77 out 101 cases. It was noted that the majority of the patients, that is $54(53.4 \%)$ cases were euthyroid followed by $22(21.7 \%)$ cases which were hypothyroid and one $(0.99 \%)$ case was Hyperthyroid which were similar to the results seen in study by Uma et al [4]. 
The Ultrasonography report was available in 74 out 101 cases, of which $43(42.5 \%)$ cases were diagnosed as colloid goitre, $22(21.7 \%)$ cases were diagnosed as thyroiditis, $5(4.9 \%)$ cases were diagnosed as Solitary Thyroid nodule, 1 (0.99\%) was diagnosed as Nodular colloid goitre with cystic change and $3(2.9 \%)$ cases were diagnosed as malignancy. were similar to the results seen in study by Dhanadia et al [5].

The cytological slide review was done in all the 101 cases.
The cases were then categorised as Benign 47 (46.5\%), Inflammatory 33 (32.6\%), Follicular Neoplasm 09 (8.9\%), and Malignant 04 (3.9\%), while $09(8.9 \%)$ cases were inadequate. These findings were similar to those seen in studies conducted by other authors mentioned in the below table. Many cases showed an overlap in the lesions where benign lesions was seen co-existing with malignant lesions like Hashimoto's thyroiditis and Papillary carcinoma. Two cases showed overlap of Hashimoto's Thyroiditis in a background of Colloid Goiter.

Table-6: Comparison of the results of present study with other studies

\begin{tabular}{|l|l|l|l|l|l|l|}
\hline Cytological Categories & Present Study & Sameer et al[2] & Sengupta et al[6] & Bagga et al[7] & Afroz et al[8] & Venkatachalapathy et al[9] \\
\hline Benign / Inflammatory & $80.1 \%$ & $81.2 \%$ & $83.14 \%$ & $90.5 \%$ & $67.6 \%$ & $61 \%$ \\
\hline Follicular Neoplasm & $8.9 \%$ & $16.9 \%$ & $16.2 \%$ & $6.7 \%$ & $21.7 \%$ & $29 \%$ \\
\hline Malignant & $3.9 \%$ & $1.97 \%$ & $3.93 \%$ & $1.2 \%$ & $8.2 \%$ & $10 \%$ \\
\hline
\end{tabular}

It was noted that out of 101 cases, clinical diagnosis was mentioned in 92 cases, of which a cytological concordance was seen in $70(77.7 \%)$ cases and discordance was seen in $22(23.9 \%)$ cases. The histopathological data was available for 15 cases in the study population of which $85 \%$ showed a cytohisto concordance.

A case that would be worth mentioning would be a $65 y e a r$ old lady who presented with a nodular enlargement of thyroid since past six months, on FNAC the cytological smears revealed highly cellular smears showing monolayered sheets of follicular cells with oxyphilic change. The impression on FNAC was given was Hurthle Cell Neoplasm. On Histopathological examination, the slides revealed the features of Tall Cell Variant of Papillary Carcinoma Thyroid. (Refer Figure 1 and 2)

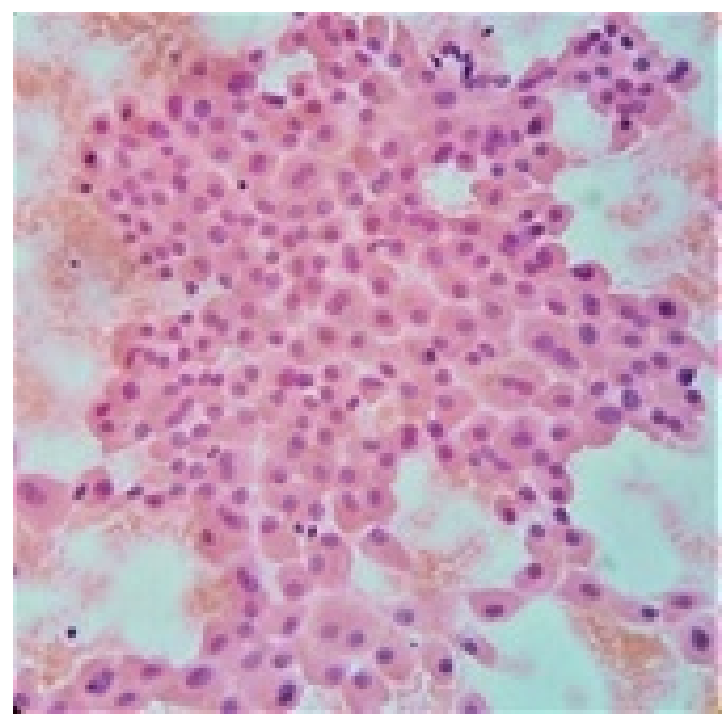

Figure 1: 10x view, Haematoxylin and Eosin Stain: A case of showing highly cellular smears with sheets of follicular cells with oxyphilic change. This case was opined as suggestive of Hurthle Cell Neoplasm.

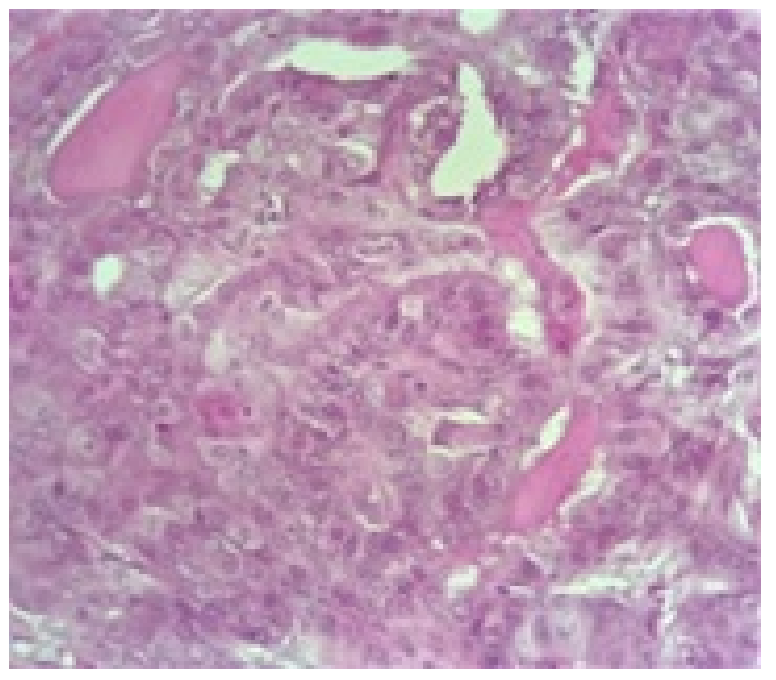

Figure 2: 10x view, Haematoxylin and Eosin Stain : Histopathological sections of the same case mentioned in Figure 05 where it was diagnosed as Hurthle Cell Neoplasm : The Histopathological sections showed the features of Tall Cell Variant of Papillary Carcinoma Thyroid..

Limitation of study: As this was a retrospective study and many of the cases were OPD based hence a detailed clinical history and examination findings were not available for few cases. 
Ultrasound, TFT was not done in $20 \%$ of the cases. Due unavailability of Anti TPO test a complete work up of thyroiditis was not done.

\section{Conclusion}

In conclusion, this study affirms the importance of FNAC as the first line screening test and hence giving a direction to the clinician for further management of the patients. However, there are a few draw backs in the methods, a reason behind missing the diagnosis on FNAC could be attributed to mainly sampling error, wherein an inadequate sample, or co-existing benign and malignant lesion where the needle does not hit the lesion and hence the representative material is not obtained. These drawbacks can be corrected by opting for ultrasound guided FNAC especially in difficult lesions.

\section{What the study adds to existing knowledge?}

In the era of evidence based medicine, FNAC place a vital role in the management of patients with thyroid lesions however a low percentage of false negatives can be avoided by inculcating ultrasound guided FNAC in difficult cases.

\section{Author'scontribution}

Data collection was done by Dr. Akshatha N. while data interpretation and manuscript writing done by both Dr. Akshatha N. and Dr. Shwetha Patil. Review of articles, references and introduction done by Dr. Akshatha N., Dr. Shwetha Patil and Dr. Basavaraj Bommanahalli. Proof reading done by Dr. Shwetha Patil.

\section{Reference}

01. Dash M, Chandrasekhar KP, Raghu K, Kethireddy S. Histopathological study of neoplastic and nonneoplastic thyroid lesions: An institutional experience of 2 years. J Evolution Med Dent Sci. $201612 ; 5(73): 5348-53511 . \quad$ doi: 10.14260/jemds/2016/1213 [Crossref][PubMed] [Google Scholar]

02. Dharrao SS, Mahajan SV. DFNAC study of various thyroid lesions and its clinical correlation in a tertiary health care center - a prospective study. MVP J Med Sci. 2017;4(2):152-155. doi: $10.18311 / \mathrm{mvpjms} / 2017 / \mathrm{v} 4 \mathrm{i2} / 8560$ [Crossref] [PubMed][Google Scholar]
03. Davidson HG, Gonzalez-Campora R. Thyroid (Fine needle aspiration of various org-ans and Body sites), In Bibbo M, editor, Comphresive cytopathology, 3rd ed. Saunders company. 2008;633-670. [Crossref][PubMed][Google Scholar]

04. Handa U, Garg S, Mohan H, Nagarkar N. Role of fine needle aspiration cytology in diagnosis and management of thyroid lesions: A study on 434 patients. J Cytol. 2008;25(1)13. doi: 10.4103/09 76-9668.82308 [Crossref][PubMed][Google Scholar]

05. Dhanadia A, Shah H, Dave A. Ultrasonographic and FNAC correlation of thyroid lesions. Gujarat Med J. 2014;69(1):75-81. [Crossref][PubMed][Google Scholar]

06. Sengupta A, Pal R, Kar S, Zaman FA, Sengupta $S$, Pal $S$. Fine needle aspiration cytology as the primary diagnostic tool in thyroid enlargement. J Nat Sci Biol Med. 2011;2(1):113-118. doi: 10.4103/0976-9668.82308 [Crossref][PubMed] [Google Scholar]

07. Bagga PK, Mahajan NC. Fine needle aspiration cytology of thyroid swellings: How useful and accurate is it?. Indian J Cancer. 2010;47(4):437. doi. org/10.4103/0019-509X.73564 [Crossref] [PubMed][Google Scholar]

08. Afroze N, Kayani N, Hasan SH. Role of fine needle aspiration cytology in the diagnosis of palpable thyroid lesions. Indian J Pathol Microbiol. 2002;45(3):241-246. [Crossref][PubMed][Google Scholar]

09. Venkatachalapathy TS, Sreeramulu PN, Krishna MR. A prospective study of clinical, sonological and pathological evaluation of thyroid nodule. Thyroid Disorders Ther. 2012;1(109):1-3. doi: 10.4172/21 67-7948.1000109 [Crossref][PubMed][Google Scholar]

10. Chandra S, Chandra H, Bisht SS. Malignancy rate in thyroid nodules categorized as atypia of undetermined significance or follicular lesion of undetermined significance - An institutional experie nce. J Cytol. 2017;34(3):144-148. doi: 10.4103/JO C.JOC_234_16 [Crossref][PubMed][Google Scholar]

11. Sukumaran R, Kattoor J, Pillai KR, Ramadas PT, Nayak N, Somanathan $T$, et al. Fine needle aspiration cytology of thyroid lesions and its correlation with histopathology in a series of 248 patients. Indian J Surg Oncol. 2014;5(3):237-41. doi: 10.1007/s13193-014-0348-x [Crossref] [PubMed][Google Scholar] 
12. Nandedkar SS, Dixit M, Malukani K, Varma AV, Gambhir S. Evaluation of Thyroid Lesions by Fineneedle Aspiration Cytology According to Bethesda System and its Histopathological Correlation. Int J Appl Basic Med Res. 2018;8(2):76-82. doi: 10.4103/ijabmr.IJABMR_169_17 [Crossref] [PubMed][Google Scholar]

13. Bhartiya R, Mallik M, Kumari N, Prasad BN. Evaluation of thyroid lesions by fine-needle aspiration cytology based on Bethesda system for reporting thyroid cytopathology classification among the population of South Bihar. Indian J Med Paediat Oncol. 2016 ;37(4):265-270. doi: 10.4103/09715851.195742 [Crossref][PubMed][Google Scholar]

14. Arif $M, H$ Sunil. Benefits and limitations of FNAC in thyroid diseases: our institutional experience. Int J Res Med Sci. 2013;1(4):435-440. doi: 10.5455/2320-6012.ijrms20131124 [Crossref] [PubMed][Google Scholar]
15. Hajmanoochehri F, Rabiee E. FNAC accuracy in diagnosis of thyroid neoplasms considering all diagnostic categories of the Bethesda reporting system: A single-institute experience. J Cytol. 2015;32(4):238-243. doi: 10.4103/09709371.171234 [Crossref][PubMed][Google Scholar]

16. M Guhamallick, S Sengupta, NK Bhattacharya, N Basu, S Roy, AK Ghosh et al. Cytodiagnosis of thyroid lesions: usefulness and pitfalls: a study of 288 cases. J Cytol. 2008;25(1):6-9. [Crossref] [PubMed][Google Scholar] 